\title{
Pseudoplectania africana (Sarcosomataceae, Pezizales), a new species from South Africa
}

\author{
Authors \\ 'Zuzana Sochorová (B) \\ ${ }^{2}$ Matteo Carbone (B) \\ 'Michaela Sedlářová (i) \\ ${ }^{3}$ Adam Polhorský () \\ ${ }^{4}$ Michal Sochor

\section{Affiliations \\ ${ }^{1}$ Faculty of Science, Palacký University Olomouc, Šlechtitelů 27, Olomouc, CZ-78371, Czech Republic. \\ ${ }^{2}$ Via Don Luigi Sturzo 173, Genova, I-16148, Italy. \\ ${ }^{3}$ Faculty of Natural Sciences, Constantine the Philosopher University in Nitra, Tr. A. Hlinku 1 Nitra, SK-94901, Slovakia \\ ${ }^{4}$ Centre of the Region Haná for Biotechnological and Agricultural Research, Crop Research Institute, Šlechtitelů 29, Olomouc, CZ-78371, Czech Republic.}

\section{Corresponding Author}

Zuzana Sochorová; e-mail: asco.sochorova@gmail.com.

\section{Dates}

Submitted: 10 February 2021 Accepted: 14 October 2021 Published: 7 March 2022

\section{How to cite this article:}

Sochorová, Z., Carbone, M., Sedlářová, M., Polhorský, A. \& Sochor, M., 2022, 'Pseudoplectania africana (Sarcosomataceae, Pezizales), a new species from South Africa', Bothalia 52(1), a1. http://dx.doi. org/10.38201/btha.abc.v52.i1.1

Copyright: () 2022. The Authors. Licensee: SANBI. This work is licensed under the Creative Commons Attribution 4.0 International License.
Background: An undescribed species of Pseudoplectania was found during an excursion in Mpumalanga.

Objectives: To describe Pseudoplectania africana M.Carbone \& Sochorová as a new species and to evaluate presence of crystals as a diagnostic character in Pseudoplectania.

Methods: The description was based on standard macro- and microscopical methods. Presence of crystals was tested for in UV light. Phylogeny was inferred using sequencing of the LSU and ITS loci.

Results: Pseudoplectania africana is characterised by shortly stipitate to sessile apothecia up to $18 \mathrm{~mm}$ broad, richly developed basal tomentum, ascospores with an eccentrically positioned, relatively small sheath, straight, sometimes bifurcate paraphyses, wavy to coiled external hairs and presence of large yellow crystals mainly in the hymenium and ectal excipulum. It was found on a decaying coniferous trunk. The species forms a distinct lineage in the clade with $P$. tasman$i c a$ and $P$. ericae. All of these three species exhibited presence of the large yellow crystals (sulphur yellow in UV light). No or only small hyaline crystals (whole mount blue in UV light) were found in $P$. nigrella, $P$. lignicola, $P$. episphagnum and P. melaena.

Conclusion: The new species represents the first report of Pseudoplectania in South Africa and probably also in the whole of continental Africa. Crystals in hymenium and excipulum appear to be an important trait in Pseudoplectania taxonomy.

Keywords: Ascomycota; crystals; fungal diversity; phylogeny; taxonomy.

\section{Introduction}

Pseudoplectania Fuckel, typified by Pseudoplectania nigrella (Pers.) Fuckel, is a genus of ascomycetes belonging to the family Sarcosomataceae Kobayasi. It includes species with hemispherical, cupulate to plane apothecia, which are sessile or stipitate, coloured in shades of black or brown, having the outer surface covered by brown to black hairs and reaching a size between ca. 0.5 and $6.0 \mathrm{~cm}$ in diameter. Typical microscopical characters of the species of Pseudoplectania are globose, hyaline, usually smooth, thick-walled ascospores, operculate, inamyloid, octosporic asci arising from simple septa, presence of two types of paraphyses (common ones and so called hymenial hairs), medulla organised as a textura intricata, ectal excipulum with a $t$. globulosa or $t$. angularis and thick-walled, septate but unbranched hairs with blunt apex (Eckblad 1968; Donadini 1987). Fruit bodies of Pseudoplectania occur on dead wood, in litter, on soil or Sphagnum. 
Nine species have been accepted by Carbone et al. (2014), namely Pseudoplectania nigrella, P. episphagnum (J.Favre) M.Carbone, Agnello \& P.Alvarado, P. melaena (Fr.) Sacc., P. ericae Donadini, P. affinis M.Carbone, Agnello \& P.Alvarado, P. tasmanica M.Carbone, Agnello \& P.Alvarado, P. stygia (Berk. \& M.A.Curtis) Sacc., P. carranzae (Calonge \& M.Mata) M.Carbone, Agnello \& P.Alvarado and $P$. ryvardenii Iturr., M.Mardones \& H.Urbina. In 2015, P. lignicola Glejdura, Kučera, Lizoň \& Kunca was described (Glejdura et al. 2015), and in 2020 P. sinica Qiao Zhang \& Jie Zhang (Zhang \& Zhang 2020). The first six species and $P$. sinica have already been characterised by molecular methods (Carbone et al. 2014; Zhang \& Zhang 2020) whilst the other four have been described only by their morphology and ecology (Calonge \& Mata 2002; Iturriaga et al. 2012; Carbone 2013; Glejdura et al. 2015). One more species belonging to this genus, Pseudoplectania kumaonensis Sanwal is regarded to be doubtful (Sanwal 1953; Carbone et al. 2014).

Many reports of Pseudoplectania have been published from different regions of the northern hemisphere (e.g. Seaver 1913; Otani 1973; Breitenbach \& Kränzlin 1981; Donadini 1987; Kristiansen 1990; Lincoff 1997; Calonge \& Mata 2002; Medardi 2006; Barseghyan \& Wasser 2008; Pant \& Prasad 2008; Iturriaga et al. 2012; Van Vooren et al. 2013; Deckerová \& Šuhaj 2014; Glejdura et al. 2015; Uzun \& Kaya 2018), while data from the southern hemisphere are much rarer (Le Gal 1953; Sandoval 2012; Carbone et al. 2014; Gates \& Ratkowsky 2016). No literature reports documenting Pseudoplectania spp. from continental Africa are known to us, with only a single report from the island of Madagascar (Le Gal 1953). In March 2018, a rich population of Pseudoplectania was discovered in Mpumalanga, South Africa, which did not match phenotypic descriptions of any of the currently known species. Especially striking were large yellow crystals found during microscopical examination in hymenium and ectal excipulum, which had been reported so far only in $P$. tasmanica (Carbone et al. 2014).

The aim of the present article is to introduce Pseudoplectania africana sp. nov., compare it with other species of the genus and evaluate presence of crystals in available Pseudoplectania spp. collections.

\section{Material and methods}

\section{Sample collection and observation}

Description of macroscopical characters is based on fresh apothecia. Microscopical characters were studied in living $\left(^{*}\right)$ cells and tissues and rehydrated material $\left(^{+}\right)$ at magnifications up to $1000 \times$, using light microscopes Olympus CX41 and CX21. The following media were used: tap water $\left(\mathrm{H}_{2} \mathrm{O}\right), 3 \%$ potassium hydroxide $(\mathrm{KOH})$, Lugol's solution (IKI), Brilliant Cresyl Blue (CRB) and Lactic Acid Cotton Blue (LACB). Nuclei were visualised in rehydrated apothecia upon staining with DAPI $\left(4^{\prime}, 6-d i-\right.$ amidino-2-phenylindole; $10 \mu \mathrm{g} / \mathrm{mL}, 10 \mathrm{~min}$, room temperature, dark) and fluorescence signal excited by a mercury lamp was combined with transmission light channel (50:50) (Olympus BX60 with attached DP73 camera). Measurements of microscopical characters were made in tap water (if not otherwise stated) directly with an ocular micrometre scale or in photographs with the PIXIMÈTre 5.10 software (Henriot \& Cheype 2020). Diameter of ascospores is given as minimal measured value - arithmetic mean - maximal measured value; $\mathrm{Q}=$ length/width ratio; $\mathrm{n}=$ sample size. Crystals were studied in exsiccates. Their solubility in $P$. africana was tested in Melzer's reagent (MLZ), 60\% ethanol, 9\% hydrochloric acid $(\mathrm{HCl})$ and $40 \% \mathrm{KOH}$. Their autofluorescence was tested using excitation by Jaxman U1C UV flashlight (3W UV LED Nichia, $365 \mathrm{~nm}$ ), which radiation was applied to mounts obliquely from above.

\section{DNA extraction, PCR amplification and sequencing}

DNA was extracted from dried apothecia using the CTAB method (Doyle \& Doyle 1987). Sequence data were generated for two loci - internal transcribed spacers (ITS) of ribosomal DNA (ITS1-5.8S rDNA-ITS2 region) using primers ITS1F (Gardes \& Bruns 1993) and ITS4 (White et al. 1990), and the large subunit of ribosomal DNA (LSU) using primers LROR and LR6 (Vilgalys \& Hester 1990). PCR was performed with Kapa polymerase (Kapa Biosystems), following a standard protocol with 37 cycles and annealing temperature of $56^{\circ} \mathrm{C}$. The PCR products were purified by precipitation with polyethylene glycol (10\% PEG 6000 and $1.25 \mathrm{M} \mathrm{NaCl}$ in the precipitation mixture) and sequenced in both directions using the Sanger method (Macrogen Europe, The Netherlands).

\section{Phylogenetic analysis}

Sequences of Pseudoplectania africana and all other available Pseudoplectania species were included in molecular analysis (Table 1), Urnula craterium (Schwein.) Fr. served as an outgroup. Sequences were assembled, edited and aligned in GENEIOUS 8.1.9 (Biomatters, New Zealand) using the MAFFT plugin (ver. 1.3.3), manually checked and corrected. Bayesian phylogeny inference for concatenated data was computed in MRBAYES (ver. 3.2.4; Ronquist et al. 2012) with $5 \times 10^{6}$ generations, sampling every 1000th tree, in two independent runs, each with 4 chains, first $50 \%\left(2.5 \times 10^{6}\right)$ generations were excluded as burn-in. The most suitable substitution model for each locus was determined in PARTITIONFINDER 2.1.1 (Lanfear et al. 2017) using the corrected AIC (AICC) and a greedy search. SYM+I+G was selected for ITS and GTR+I+G for LSU. Single-locus phylogenies 
Table 1. List of collections used in the phylogenetic study together with their GenBank accession numbers. Sequences newly generated for this study in bold font.

\begin{tabular}{|c|c|c|c|c|c|}
\hline \multirow[t]{2}{*}{ Species } & \multirow{2}{*}{$\begin{array}{l}\text { Identification code } \\
\text { in GenBank }\end{array}$} & \multirow[t]{2}{*}{ Country, collection date } & \multirow{2}{*}{$\begin{array}{l}\text { Herbarium } \\
\text { code }\end{array}$} & \multicolumn{2}{|c|}{ GenBank accession numbers } \\
\hline & & & & ITS & LSU \\
\hline Pseudoplectania affinis & $\begin{array}{l}\text { PDD } 81842 \\
\text { (holotype) }\end{array}$ & New Zealand, 24 Nov. 2004 & PDD 81842 & JX669826 & JX669865 \\
\hline Pseudoplectania africana & ZE59/18 (holotype) & South Africa, 5 Mar. 2018 & PRM 954013 & MT496892 & MT496884 \\
\hline Pseudoplectania episphagnum & ERD 6456 & Spain, 30 May 2015 & PRM 954123 & MT502112 & MT500571 \\
\hline Pseudoplectania episphagnum & TUR 064171 & Finland, 30 May 1948 & TUR 064171 & KF305712 & ------- \\
\hline Pseudoplectania episphagnum & TUR 064173 & Finland, 26 Jun. 1943 & TUR 064173 & KF305711 & KF305724 \\
\hline Pseudoplectania episphagnum & $\begin{array}{l}\text { G00566257 } \\
\text { (isolectotype) }\end{array}$ & Switzerland, 20 May 1945 & G00566257 & ------- & MT782281 \\
\hline Pseudoplectania ericae & MCVE 27581 & Italy, 23 Dec. 2012 & MCVE 27581 & KF305721 & KF305731 \\
\hline Pseudoplectania ericae & TUR-A 195789 & Spain, 16 Jan. 2007 & TUR-A 195789 & JX669822 & JX669862 \\
\hline Pseudoplectania ericae & TUR-A 195790 & Spain, 17 Feb. 2010 & TUR-A 195790 & JX669823 & JX669863 \\
\hline Pseudoplectania ericae & ZE1228/18 & France, 28 Dec. 2015 & PRM 954131 & MT476910 & MT476900 \\
\hline Pseudoplectania ericae & CA1/18 & Greece, 17 Mar. 2018 & PRM 954125 & MT476909 & MT496885 \\
\hline Pseudoplectania ericae & MCVE 31255 & France, 2 Dec. 2019 & MCVE 31255 & MT498082 & MT491442 \\
\hline Pseudoplectania ericae & MCVE 30339 & Italy, 2 Jan. 2020 & MCVE 30339 & MT226749 & ------- \\
\hline Pseudoplectania ericae & Sousa & Portugal, 9 Feb. 2019 & $\begin{array}{l}\text { pers. herb. E. } \\
\text { Sousa }\end{array}$ & MT498083 & ------- \\
\hline Pseudoplectania lignicola & HR89756 (paratype) & Czech Republic, 1 Apr. 2011 & HR 89756 & MT496886 & MT496882 \\
\hline Pseudoplectania lignicola & SAV 105/17 & Slovakia, 21 Apr. 2010 & SAV 105/17 & MT496881 & MT496883 \\
\hline Pseudoplectania lignicola & MCVE 27580 & Canada, 17 Jul. 2011 & MCVE 27580 & KF305713 & KF305726 \\
\hline Pseudoplectania lignicola & TUR 172564 & Finland, 06 Nov. 2004 & TUR 172564 & -------- & JX669860 \\
\hline Pseudoplectania melaena & MCVE 27579 & France, 07 Apr. 2008 & MCVE 27579 & KF305717 & KF305728 \\
\hline Pseudoplectania melaena & TUR-A 198588 & USA, 21 Apr. 2006 & TUR-A 198588 & KF305719 & KF305729 \\
\hline Pseudoplectania melaena & NY 54130 & USA, 5 Apr. 2008 & NY 54130 & KF305718 & KF305730 \\
\hline Pseudoplectania melaena & NY 96459 & USA, 12 May 1947 & NY 96459 & KF305720 & ------- \\
\hline Pseudoplectania nigrella & MCVE 27396 & Italy, 1 May 2009 & MCVE 27396 & KF305715 & KF305725 \\
\hline Pseudoplectania nigrella & MCVE 27397 & Italy, 31 May 2009 & MCVE 27397 & ------- & MT491441 \\
\hline Pseudoplectania nigrella & MCVE 27582 & Italy, 13 Apr. 2013 & MCVE 27582 & KF305716 & KF305727 \\
\hline Pseudoplectania nigrella & TUR-A 198587 & USA, 30 Apr. 1999 & TUR-A 198587 & KF305714 & ------- \\
\hline Pseudoplectania nigrella & Fan \& Guo 1500201 & China, 15 Aug. 2015 & & KX394804 & -------- \\
\hline Pseudoplectania sinica & LYSO2 (holotype) & China, 13 May 2017 & $\begin{array}{l}\text { CGMCC } \\
3.19892\end{array}$ & MN396767 & MN396768 \\
\hline Pseudoplectania tasmanica & $\begin{array}{l}\text { MCVE } 27583 \\
\text { (holotype) }\end{array}$ & Australia, 22 Dec. 2012 & MCVE 27583 & KF305722 & KF305732 \\
\hline Pseudoplectania tasmanica & MCVE 27584 & Australia, 22 Dec. 2012 & MCVE 27584 & KF305723 & KF305733 \\
\hline Urnula craterium & 30.15 .291 .11 & France, 13 Jan. 2011 & $\begin{array}{l}\text { pers. herb. } \\
\text { R. Dougoud } \\
30.15 .291 .11\end{array}$ & KF311230 & KF305734 \\
\hline
\end{tabular}


were computed with similar settings, only the temp parameter was set to 0.01 for ITS to improve chain mixing.

\section{Phylogenetic results}

$P$. africana forms a distinct lineage in the clade with P. tasmanica and P. ericae (Figure 1). Although it clearly appears to be the closest (known) relative of the former species according to the ITS locus (Bayesian posterior probability, PP=0.93; Sup. Figure 1), LSU provided an ambiguous signal due to a lack of shared apomorphic SNP's in the clade, which resulted in clustering of $P$. africana and $P$. ericae with very low support $(P P=0.8$; Sup. Figure 2). Subsequently, the concatenated dataset did not provide a well-supported phylogeny in this clade either (Figure 1). However, branch lengths indicate relatively large divergence between the three species (sequence divergence $\pm 20 \%$ and $1.8 \%$ at ITS and LSU, respectively, between $P$. africana and $P$. ericae, and $21 \%$ and $1.7 \%$ between $P$. africana and $P$. tasmanica).

\section{Taxonomy}

Pseudoplectania africana M.Carbone \& Sochorová, sp. nov. (Figures 2, 3, 4 A, B).

MycoBank MB 838266.

TYPE: SOUTH AFRICA, Mpumalanga: Ehlanzeni district,
$8.3 \mathrm{~km}$ SSW of the NG Kerk in Sabie, $25^{\circ} 10^{\prime} 7.6^{\prime \prime} \mathrm{S} /$ $30^{\circ} 45^{\prime} 49.2^{\prime \prime} \mathrm{E}, 1480 \mathrm{~m}$ asl, on a decaying trunk (probably Pinus sp.), 5 Mar. 2018, Z. Egertová (Sochorová) \& M. Sochor (PRM 954013 - holotype, TUR-A 208915 - isotype, PREM - isotype).

Diagnosis: Differs from other Pseudoplectania species in a combination of the following characters: shortly stipitate or sessile, brown to black, sometimes olivetinged apothecia up to $18 \mathrm{~mm}$ in diameter, richly developed basal tomentum; smooth ascospores having an eccentrically positioned, relatively small sheath, straight, often bifurcate paraphyses, wavy to coiled external hairs and presence of large yellow crystals mainly in hymenium and ectal excipulum.

Etymology: From the Latin adjective 'Africanus-a-um', referring to the African continent.

Description: Apothecia up to $18 \mathrm{~mm}$ in diameter, hemispherical or cup-shaped, becoming flattened, often irregularly deformed by a mutual pressure, shortly stipitate or sessile. Hymenium smooth, shiny, brown to brownish black, in some apothecia with an olivaceous tinge. External surface tomentose, brownish black, darker than the hymenium, base with a richly developed black tomentum. Stipe short or lacking, up to $3 \mathrm{~mm}$ long and $2 \mathrm{~mm}$ wide, black. Flesh pale greyish, rubbery. Occurring in groups or clusters.

Ascospores in $\mathrm{H}_{2} \mathrm{O}^{*}$ globose, 10.5-11.4-13 $\mu \mathrm{m}(\mathrm{n}=$ 100); in $\mathrm{H}_{2} \mathrm{O}^{+}$globose or rarely subglobose, 9-10.7-13

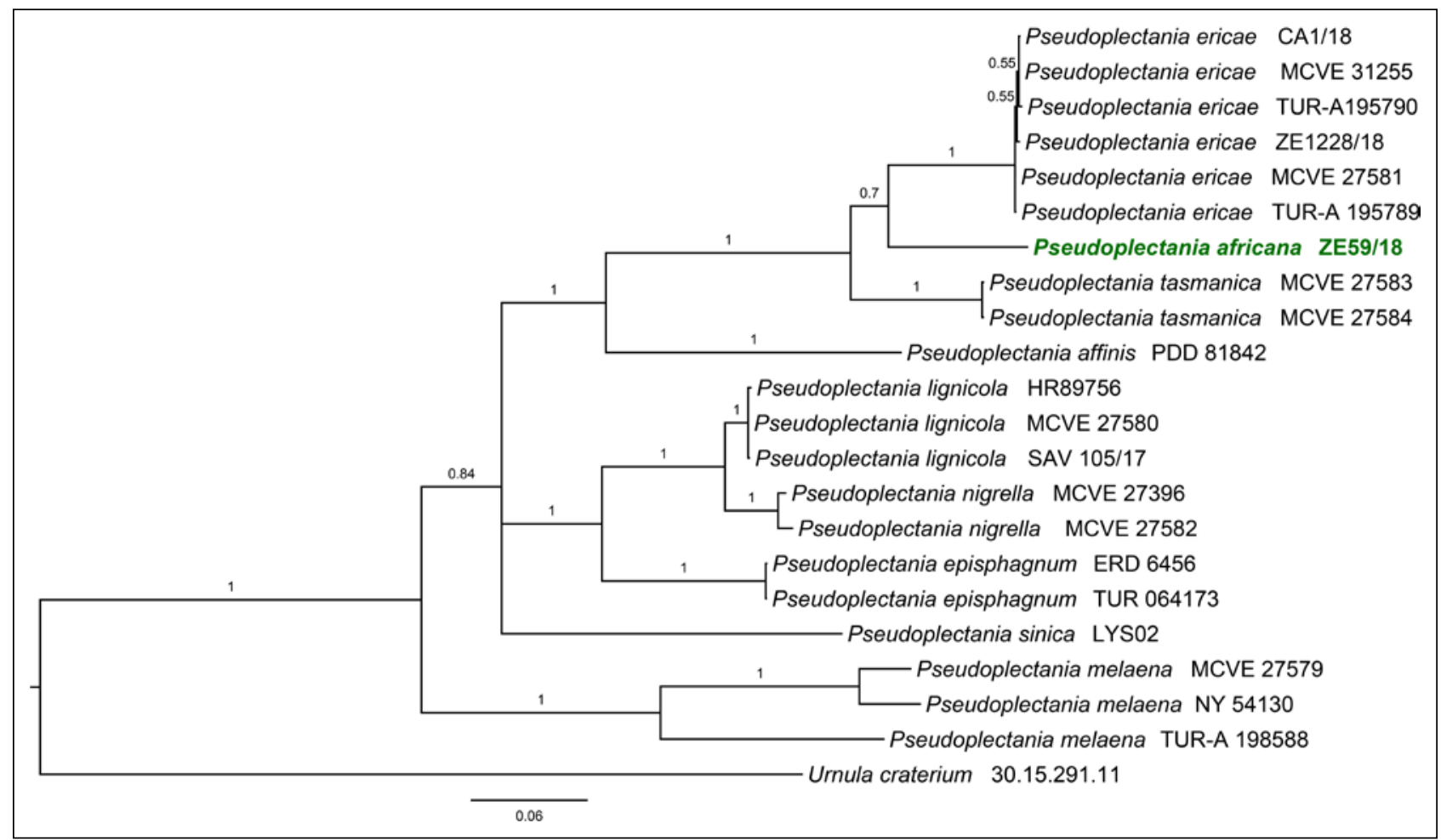

Figure 1. Bayesian phylogeny inference based on concatenated alignment of LSU and ITS sequences. Bayesian posterior probabilities are shown above branches; Urnula craterium serves as an outgroup. 
$\mu \mathrm{m}(\mathrm{n}=100), \mathrm{Q}=1.00-1.06$; in heated $\mathrm{LACB}^{+}$globose or less often subglobose, 9-10.7-13 $\mu \mathrm{m}(\mathrm{n}=100), \mathrm{Q}$ =1.00-1.08; hyaline, smooth, thick-walled, with vacuolar content, 1-4 nucleate, surrounded by an eccentrically arranged globose membranous sheath, which in its most convex part exceeds the sporal wall for up to $2 \mu \mathrm{m}$; de Bary bubbles induced in heated LACB; ascospores germinating with one hypha. Asci narrow-

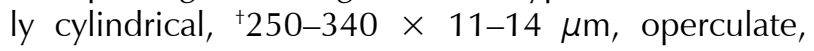
operculum ${ }^{+} 4.5-6 \mu \mathrm{m}$ broad; inamyloid, 8-spored, pars sporifera ${ }^{\dagger} 75-83 \mu \mathrm{m}$ when all 8 ascospores are fully developed, base flexuous, tapered, arising from simple septa. Paraphyses of two types: 1) cylindrical, apical cell ${ }^{+} 12-29 \times 2-3.5 \mu \mathrm{m}$, lower cells ${ }^{+} 1-2.5 \mu \mathrm{m}$ in diam., septate, branched, sometimes anastomosing with paraphyses of the same type or with the hymenial hairs, light brownish in the upper half; apex slightly enlarged, simple, bifurcate or less often diverticulated to lobed; some paraphyses showing short diverticula growing from the lower elements; 2) so called hymenial hairs cylindrical, measuring ${ }^{+} 2-3 \mu \mathrm{m}$ in diam., very light brownish, with a single septum at the base; apex straight, hooked or bent in right or obtuse angle, ${ }^{+} 2-3 \mu \mathrm{m}$ broad; cytoplasm in both types cyanophilic, walls cyanophobic. Crystals in hymenium very abundant, yellow, angular, cracked, sometimes very long (to over the whole thickness of hymenium), up to $60 \mu \mathrm{m}$ wide, oriented with their long axis like the hymenium, not dissolving in $\mathrm{KOH}(40 \%), \mathrm{HCl}(9 \%)$, ethanol $(60 \%)$ and MLZ. Subhymenium ${ }^{\dagger} 25-55 \mu$ m thick, structured as a dense textura intricata with cylindrical septate hyphae. Medullary excipulum ${ }^{\dagger} 200-380 \mu \mathrm{m}$ thick at flanks, formed by a slightly gelified textura intricata, hyphae cylindrical, septate, subhyaline, ${ }^{*} 2-12 \mu \mathrm{m}$ wide, ${ }^{\dagger} 1.5-6.5 \mu \mathrm{m}$ wide, walls up to $0.8 \mu \mathrm{m}$ thick; cytoplasm cyanophilic, walls cyanophobic. Ectal excipulum ${ }^{+} 40-120 \mu \mathrm{m}$ thick, composed of a textura globulosaangularis, cells thick-walled, in the inner layer subhyaline, ${ }^{+}(7) 12-24 \times(5) 12-21 \mu \mathrm{m}$, in the $2-4$ most external rows with blackish-brown walls, ${ }^{+5}$-15 $\times$ 4-12 $\mu \mathrm{m}$, walls cyanophobic; containing crystals of the same character like in hymenium, but smaller. External hairs emerging from the external layer of the ectal excipulum, cylindrical, ${ }^{\dagger}$ ca. 500-3000 $\mu \mathrm{m}$ long, 5-8(-10) $\mu \mathrm{m}$ diam., with walls up to $1.5 \mu \mathrm{m}$ thick, septate, wavy or coiled; brown, unbranched, with blunt apex. Many very small hairs, up to ${ }^{\dagger} 30 \mu \mathrm{m}$ long, are present among the longer ones. Basal tomentum composed of very long cylindrical hairs looking similar to the external hairs, ${ }^{+5}-7 \mu \mathrm{m}$ diam., walls up to $1.1 \mu \mathrm{m}$ thick. Section in UV light - most of structures blue (subhymenium paler than hymenium, medulla and ectal excipulum), outline of ascospores whitish, external hairs and basal tomentum black, crystals sulphur yellow.

Habitat and distribution: The apothecia grew in a forest patch surrounded by logged pine plantations, on a decaying mossy trunk. Microscopical examination of the substrate showed a typical structure of a conifer wood. Resin canals further indicated the substrate was most likely Pinus sp. (alien in South Africa; van Wyk \& van Wyk 2013).

The species is so far known and confirmed only from the type locality. Although no Pseudoplectania species have been reported in the checklist of macrofungi of South Africa (Kinge et al. 2020), we are aware of the existence of four collections identified as Pseudoplectania nigrella housed in the PREM fungarium (R. VenterJacobs pers. comm.). Unfortunately, our attempts to loan these specimens for verification of their identification have not been successful.

\section{Evaluation of presence of the crystals and appearance in UV light}

Beside $P$. africana (Figures 3A-C, Figures 4A, B), large yellow crystals have been confirmed in $P$. tasmanica (Figures 4D, F, G) and newly found in $P$. ericae (Figures $4 \mathrm{C}, \mathrm{E}, \mathrm{H})$, i.e. the three closely related species. The crystals are located mostly in the hymenium and ectal excipulum, less so in the medullary excipulum or subhymenium, and appear sulphur yellow in UV light. Hymenium, subhymenium, medullary and ectal excipulum are in shades of blue, outline of ascospores whitish and hairs and basal tomentum black. All other species available for our study ( $P$. episphagnum, $P$. lignicola, $P$. melaena and $P$. nigrella) lack these crystals; they contain only small hyaline crystals, which are most abundant in the medulla, but occur also in the hymenium, subhymenium and ectal excipulum. Therefore, the whole slide has shades of blue in UV light, only the outline of the ascospores is whitish with hairs and tomentum black (Figure 5). The quantity of crystals varies strongly between collections. In some of them, including the neotype of $P$. nigrella (KL BK-4914), aggregates of the crystals can be found, which look pale blue in UV light. As already mentioned in the material and methods chapter, studies on crystals have been performed on dry material. Whether the crystals are also present in vital collections is yet to be verified. Collections of $P$. affinis, $P$. carranzae, $P$. ryvardenii, $P$. sinica and $P$. stygia were not available.

\section{Additional collections examined (collections studied for presence of crystals marked 泫):}

\section{Pseudoplectania episphagnum}

FINLAND, Lapland: Ranua, $6 \mathrm{~km} \mathrm{~N}$ of the church, on 

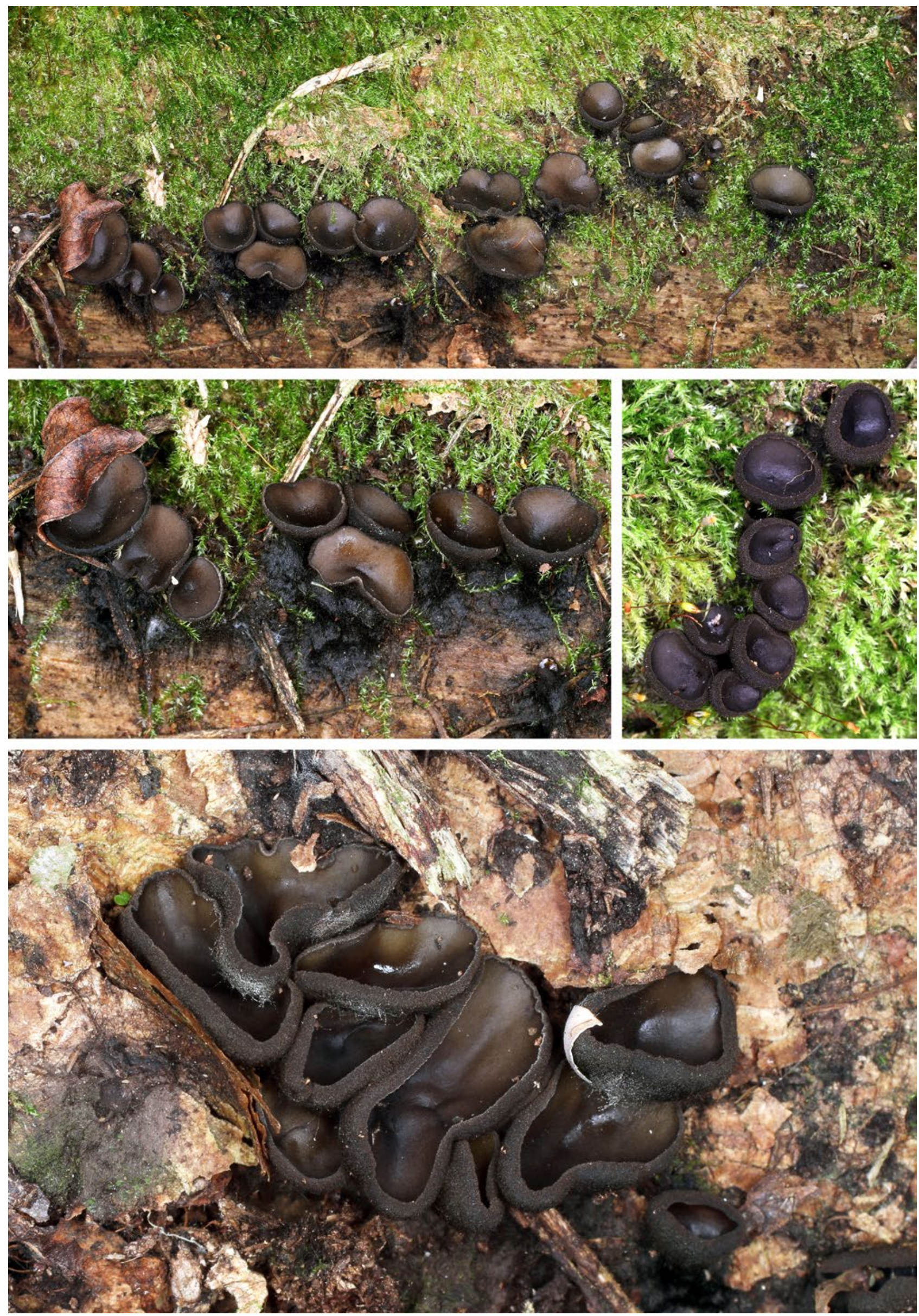

Figure 2. Pseudoplectania africana - apothecia in situ (PRM 954013). Photos: Z. Sochorová. 

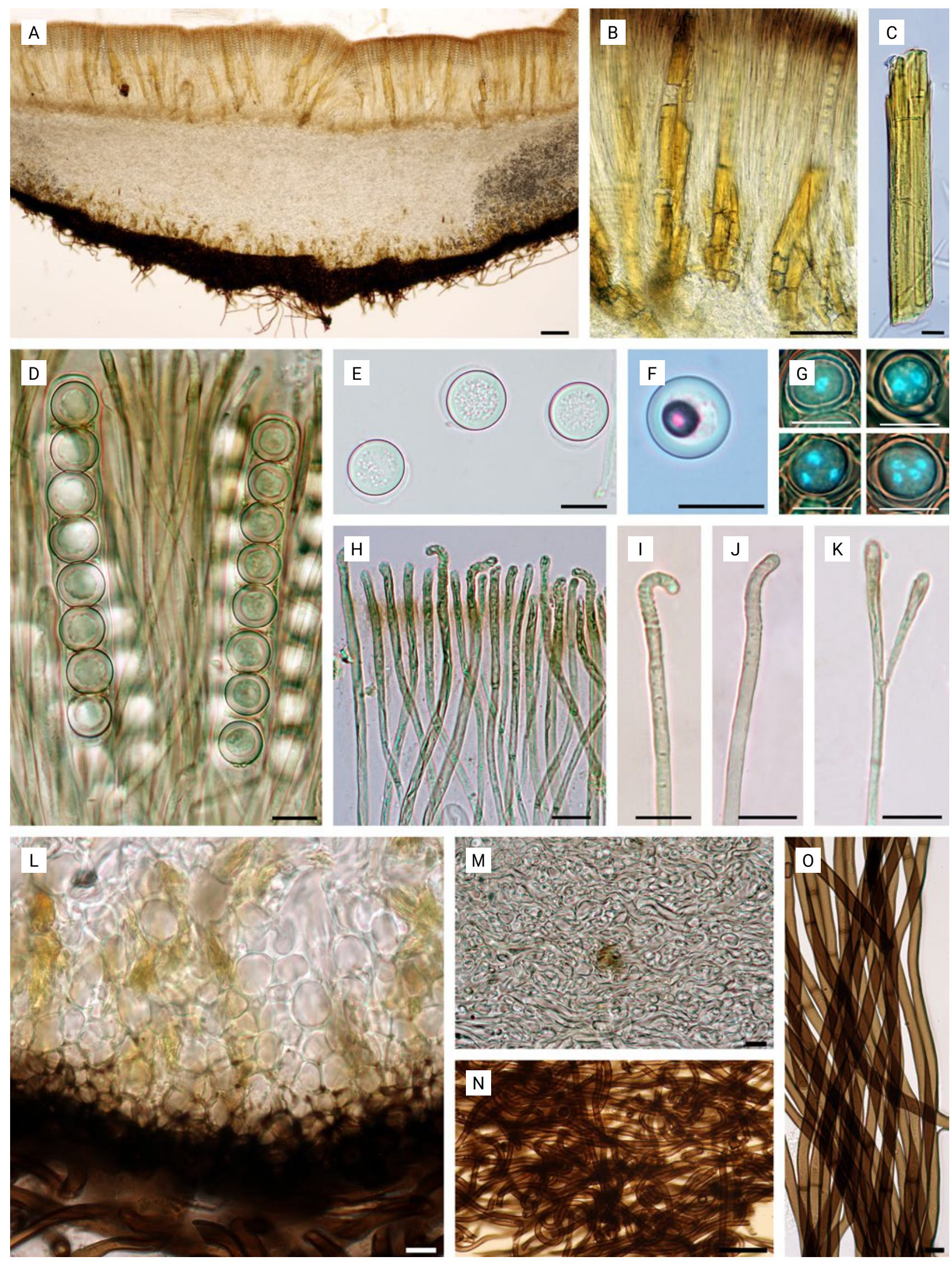

Figure 3. Pseudoplectania africana - microscopical characters (PRM 954013); A, section of an apothecium ( ${ }^{+}$in tap water); B, crystals in hymenium (in tap water); C, crystal freely floating in the mount (in tap water); D, asci with ascospores and paraphyses $\left({ }^{+}\right.$in tap water); $\mathrm{E}$, free ascospores ( ${ }^{+}$in tap water); $\mathrm{F}$, ascospore with de Bary bubble ( ${ }^{+}$stained with LACB); G, nuclei in ascospores ( ${ }^{+}$stained with DAPI); $\mathrm{H}$, two types of paraphyses ( ${ }^{+}$in tap water); I, J, hymenial hairs ( ${ }^{+}$in tap water); K, bifurcate paraphyse $\left({ }^{+}\right.$in tap water); L, ectal excipulum ( ${ }^{+}$in tap water); $\mathrm{M}$, medullary excipulum ( ${ }^{+}$in tap water); $\mathrm{N}$, external hairs $\left({ }^{+}\right.$in tap water); $\mathrm{O}$, basal tomentum $\left(^{+}\right.$in tap water). Scale bars: $\mathrm{A}=100 \mu \mathrm{m} ; \mathrm{B}, \mathrm{N}=50 \mu \mathrm{m}, \mathrm{C}-\mathrm{M}, \mathrm{O}=10 \mu \mathrm{m}$. Photos: A-F, H-O, Z. Sochorová; $\mathrm{G}, \mathrm{M}$. Sedlářová. 

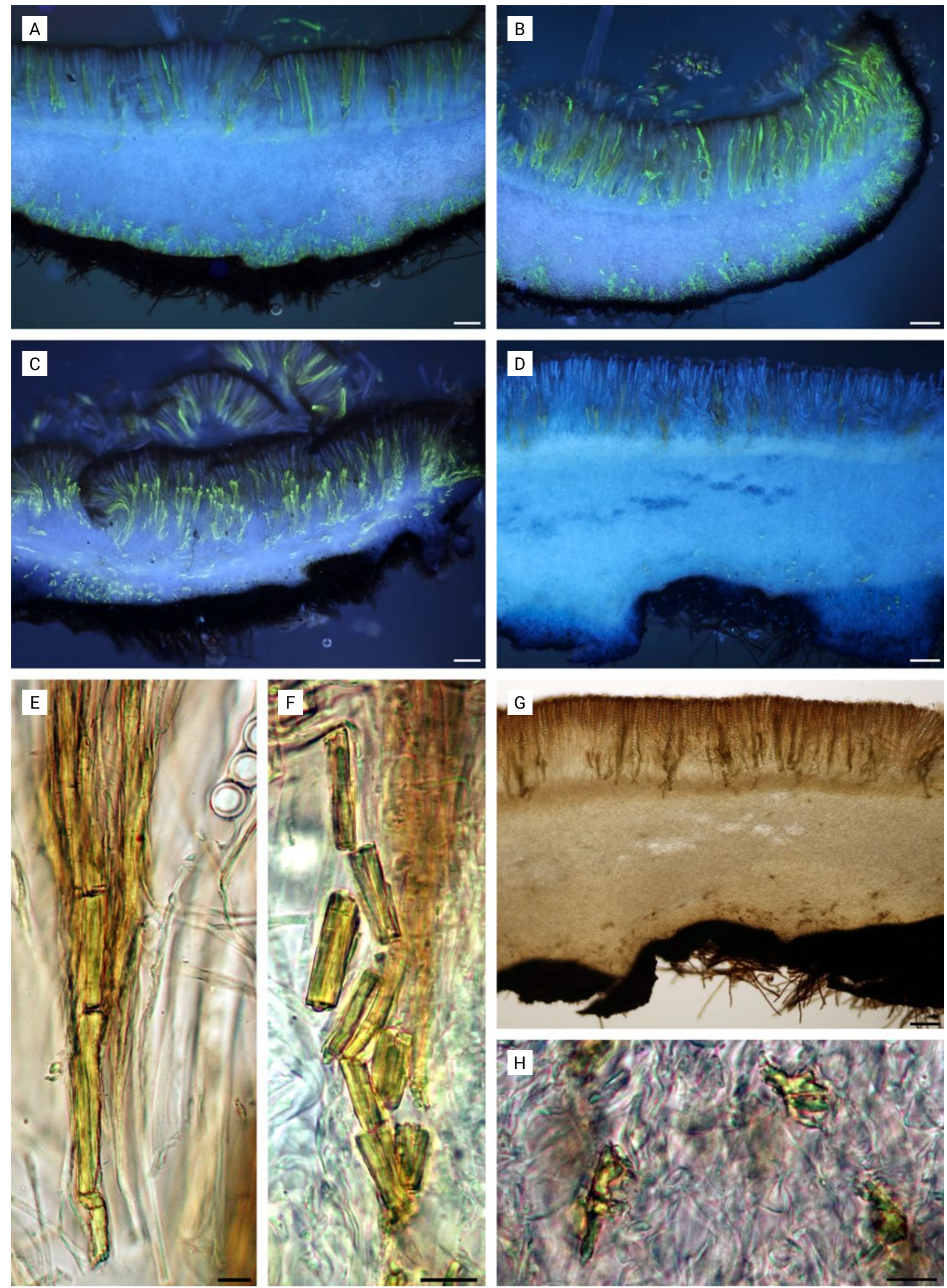

Figure 4. Pseudoplectania spp. - crystals and appearance in UV light; $A, B, P$. africana (PRM 954013) - sections in UV light; C,E, H, P. ericae - C, section in UV light (PRM 954125); E, crystals in hymenium (PRM 954124, in tap water); $\mathrm{H}$, crystals in ectal excipulum (PRM 954124, in tap water); D, F, G, P. tasmanica (MCVE 27583); D, section in UV light; F, crystals in hymenium (in tap water); G, section of the apothecium (in tap water). Scale bars: $A-D, G=100 \mu \mathrm{m} ; \mathrm{E}, \mathrm{F}, \mathrm{H}=10 \mu \mathrm{m}$ 

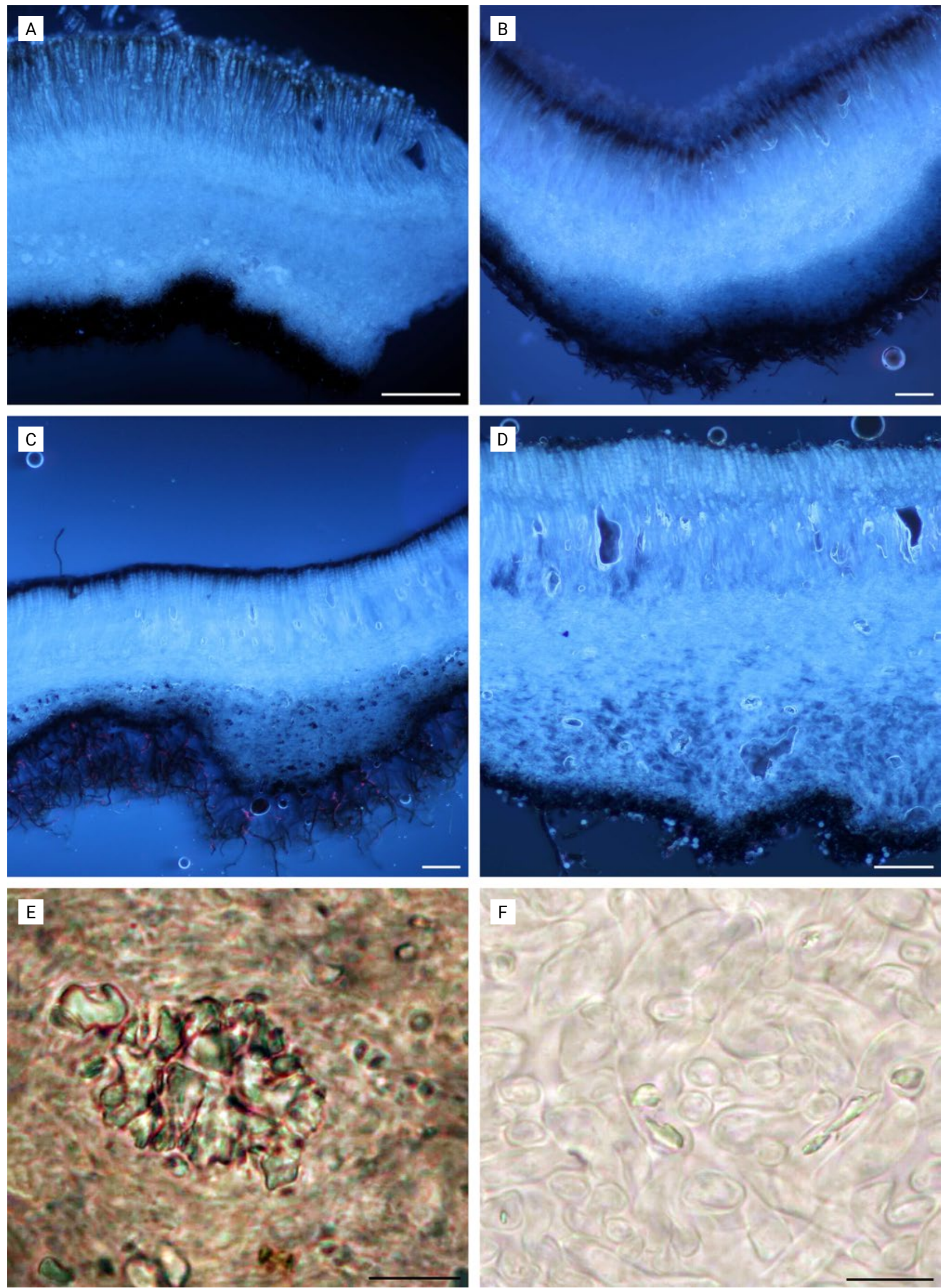

Figure 5. Pseudoplectania spp. - crystals and appearance in UV light; $A, E, F, P$. nigrella; A, section in UV light (KL BK-4914); E, aggregate of crystals in excipulum (KL BK-4914, in tap water); F, crystals in excipulum (BRNM 728214, in tap water); B, P. lignicola (PRM 954130) - section in UV light; C, P. episphagnum (PRM 954123) - section in UV light; D, P. melaena (BRNM 705053) - section in UV light. Scale bars: $\mathrm{A}=200 \mu \mathrm{m} ; \mathrm{B}-\mathrm{D}=100 \mu \mathrm{m}, \mathrm{E}, \mathrm{F}=10 \mu \mathrm{m}$ 
Sphagnum fuscum in a bog, 26 Jun. 1943, leg. A.V. Auer, det. T. Ulvinen (TUR 064173 - as Pseudoplectania sphagnophila, PRM 954134);

SPAIN, Asturias: Santa María del Puerto, Vega Cimera, on Sphagnum sp., 30 May 2015, leg. P. Zapico, det. E. Rubio (PRM 954123 -

SWITZERLAND, Vaud: Le Chenit, Le Sentier, vallée de Joux, among Sphagnum sp., 20 May 1945, leg. et det. J. Favre (G00566257 - isolectotype -

\section{Pseudoplectania ericae}

FRANCE, Var: Hyères, Porquerolles island, under Erica arborea and Cistus sp., 28 Dec. 2015, leg. J.-M. Moingeon, det. G. Moyne (PRM 954131 entales: Argelès-sur-Mer, close to Château de Valmy, under Erica arborea, 2 Dec. 2019, leg. et det. M. Gomez (MCVE 31255);

GREECE, Chalkidiki: lerissos, Gavriadia, under Erica cf. manipuliflora, 17 Mar. 2018, leg. et det. C. Agnello (PRM 954125 -

ITALY, Liguria: Genova, Sestri Levante, Punta Baffe, in the ground on roots and buried sticks of Erica arborea, 23 Dec. 2012, leg. et det. M. Carbone \& F. Boccardo (MCVE 27581, PRM 954132 ;

PORTUGAL, Norte Region: Oleiros, Vila Verde, under Erica sp., 9 Feb. 2019, E. Sousa (pers. herb.).

SPAIN, Cáceres: Talayuela, 8 Feb. 2013, on sandy soil, leg. et det. E. Rubio (PRM 954124 -

\section{Pseudoplectania lignicola}

CANADA, British Columbia: Fernie, Island Lake, on rotting and mossy wood of conifers, 17 Jul. 2011, leg. J. Harnisch, det. M. Carbone \& C. Agnello (MCVE 27580 as $P$. nigrella).

CZECH REPUBLIC, Hradec Králové Region: Nový Hradec Králové, 50¹0’45”N / 1554'15"E, 260 m asl, among Leucobryum glaucum in a mixed forest of Picea abies and Pinus sylvestris, 1 Apr. 2011, leg. Z. Egertová \& M. Sochor, det. S. Glejdura (HR 89756 - paratype Karlovy Vary Region: Vysoká u Staré Vody, 4959'10"N $/ 12^{\circ} 31^{\prime} 51^{\prime \prime} \mathrm{E}, 680 \mathrm{~m}$ asl, on an old twig and on needles among twigs, in a Picea monoculture, 6 May 2017, leg.

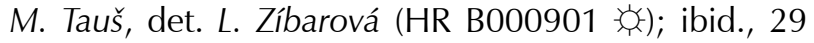
Mar. 2018, leg. M. Tauš, det. V. Halasů (PRM 954130 $14^{\circ} 51^{\prime} 35.9^{\prime \prime} \mathrm{E}, 360 \mathrm{~m}$ asl, in a relict Pinus forest, 20 Mar. 2020, leg. J. Št’astný, det. V. Halasů (PRM 954129 - ¿’́).

FINLAND, Varsinais-Suomi: Perniö, Mutainen, on a mossy stump of Picea abies, 6 Nov. 2004, leg. S. Tuominen, det. S. Huhtinen (TUR 172564, as P. nigrella).
SLOVAKIA, Banská Bystrica Region: Nízké Tatry Mts., ca $3 \mathrm{~km} \mathrm{~N}$ of Hiadel' village, $48^{\circ} 50^{\prime} 7.38^{\prime \prime} \mathrm{N} /$ $19^{\circ} 18^{\prime} 39.84^{\prime \prime} \mathrm{E}, 700 \mathrm{~m}$ asl, in a mixed forest (Picea $a b$ ies, Abies alba, Larix decidua), on wood of Abies alba, 21 Apr. 2010, leg. et det. V. Kučera (SAV 105/17); Žilina Region: Zuberec - $1.9 \mathrm{~km} \mathrm{E} \mathrm{of} \mathrm{the} \mathrm{St.} \mathrm{Vendelín} \mathrm{church,}$ on the ground, in moss, on strongly rotten Picea abies trunk and immersed branches in moss, $49^{\circ} 15^{\prime} 34.4^{\prime \prime} \mathrm{N}$ / 19³8'20.7"E, 825 m asl, 1 Apr. 2017, leg. M. Krivuš, det. A. Polhorský (pers. herb. A. Polhorský, AP17109 -

\section{Pseudoplectania melaena}

CZECH REPUBLIC, Moravian-Silesian Region: Bílá, Salajka, $850 \mathrm{~m}$ asl, on a dead Abies trunk covered with mosses, 30 Jun. 1971, leg. et det. J. Kuthan (BRA CR33022 2 ; ; South Bohemian Region: Pivonice u Pohorské Vsi, Žofínský prales NNR, on a decaying stem of Abies alba, in a mixed forest with Picea abies, Abies alba and Fagus sylvatica, 9 Apr. 2008, leg. J. Hlásek, det. P. Špinar (CB 17686 s', BRNM 739398 ; South Moravian Region: Adamov, Křtinský potok valley, on a decaying trunk of Abies alba, 15 Apr. 1951, leg. F. Valkoun, det. F. Šmarda, rev. J. Moravec (BRNM 705053 -

ITALY, Veneto: Belluno, Bosco del Cansiglio, on mossy dead wood of Abies alba, 25 Mar. 2012, leg. et det. E. Campo \& M. Carbone (MCVE 27433, PRM 954133).

\section{Pseudoplectania nigrella}

AUSTRIA, Carinthia: Bodental, in Picea abies forest, $1050 \mathrm{~m}$ asl, 18 May 1976, leg. et det. H. Engel (KL BK4914 - neotype 凉, PRM 954135 攵).

CZECH REPUBLIC, Central Bohemian Region: Borovsko, $49^{\circ} 41^{\prime} 8.3^{\prime \prime} \mathrm{N} / 15^{\circ} 6^{\prime} 42.9^{\prime \prime} \mathrm{E}, 410 \mathrm{~m}$ asl, on the ground among moss, 28 Mar. 2016, leg. P. Včelička, det. V. Halasů (PRM 954128 ; $750 \mathrm{~m}$ NNE of the Dolní Jezberná hill, 4948'55.4"N / 14 ${ }^{\circ} 14^{\prime} 27.2^{\prime \prime} \mathrm{E}, 360 \mathrm{~m}$ asl, in a coniferous forest with Picea, Pinus and Abies, 2 Apr. 2018, leg. P. Včelička, det. V. Halasů (PRM 954126 Šebeň, 49 24'32"N / 1603'47"E, 560-626 m asl, under Picea and Corylus, 25 Mar. 2015, leg. V. Antonín et al., det. H. Ševčíková (BRNM 766905 梠); South Bohemian Region: Tritim, Hněvkovický les, 49¹0'49"N / $14^{\circ} 28^{\prime} 23^{\prime \prime} \mathrm{E}, 445 \mathrm{~m}$ asl, on Picea needles among moss, 21 Mar. 2018, leg. M. Kofroňová, det. V. Halasů (PRM 954127 ; $)$; South Moravian Region: Borotín u Boskovic, Borotínské čihadlo, NW of the village, 400-480 m asl, in moss and needles on the ground, 18 May 1996, leg. et det. J. Vágner (BRNM 603997 nice, $600 \mathrm{~m}$ asl, in moss under Alnus sp. and Picea abies, 15 Apr. 2000, leg. et det. Z. Bieberová (BRNM 728142 - $)$; Rudice, Seč quarry, 49 20'22"N / 16²3'33"E, on the ground under Picea abies and Pinus sylvatica, 4 Apr. 2019, leg. et det. V. Antonín \& H. Ševčíková (BRNM 815866 (’) Z Ždárec, $2000 \mathrm{~m}$ SE of the church, $460 \mathrm{~m}$ 
asl, in moss under Picea, 17 Apr. 2005, leg. et det. Z. Bieberová (BRNM 728214 凉).

ITALY, Valle d'Aosta: Morgex (AO), Arpy, on rotten mossy wood of Picea abies, 31 May 2009, M. Carbone (MCVE 27397).

SLOVAKIA, Trnava Region: Lakšárska Nová Ves - Bežnisko military area, $200 \mathrm{~m}$ asl, in mosses on sandy soil, 25 Apr. 2008, leg. et det. V. Kučera (BRA CR14162 梠); Žlina Region: Oravská Polhora - Slaná Voda, in a swampy Picea forest with Sphagnum, $200 \mathrm{~m}$ asl, 26 Apr. 2011, leg. I. Kautmanová, det. S. Glejdura (BRA CR17264 (t); Pribylina, Podbanské, Hrdovo, behind the Kokavský bridge, in moss in a Picea forest, 27 Apr. 2011, leg. et det. I. Kautmanová (BRA CR17270 凉).

\section{Pseudoplectania tasmanica}

AUSTRALIA, Tasmania: Duckhole Lake, on mossy wood, 22 Dec. 2012, leg. G. Gates (MCVE 27583 holotype

\section{Discussion}

Apart from molecular analyses, delimitation of species within the genus Pseudoplectania is possible only through a combination of their ecology and morphological characters. The most recent key (Carbone et al. 2014) places emphasis mainly on the substrate, geography, size of apothecia, presence/absence of stipe and eventually its length, shape and furcation of paraphyses and the character of external hairs. Ascospores seem to be of a low importance being globose, hyaline, smooth (with an exception of $P$. ryvardenii) and in the same size range (9.0$13.5 \mu \mathrm{m})$ in all known species. Glejdura et al. (2015) introduced the position of the membranous sheath surrounding the ascospores as a new diagnostic character. It seems that not only the position, but also the size of the sheath has a taxonomic value, although information on this character is lacking in some species. Pseudoplectania africana and the two phylogenetically closest species $P$. tasmanica and P. ericae share an eccentrically positioned sheath, which is distinctly smaller than in $P$. nigrella, $P$. lignicola and P. melaena [compare illustrations in Glejdura et al. (2015), Carbone et al. (2014), Rubio et al. (2013) and this paper]. Another important character shared by $P$. africana, $P$. tasmanica and $P$. ericae is the large yellow crystals located mainly in hymenium and ectal excipulum, appearing sulphur yellow in UV light.

Pseudoplectania africana, beside its genetic profile, can be characterised by the following main features: shortly stipitate or sessile apothecia, ascospores surrounded by a relatively small, eccentrically arranged membranous sheath and presence of large yellow crystals especially in the hymenium and ectal excipulum. So far, it is probably the only species of Pseudoplectania reported from continental Africa. In the following, comparison of $P$. africana with other species of the genus is provided.

Pseudoplectania ericae differs in smaller apothecia, which do not exceed $1 \mathrm{~cm}$ in diameter, bi- to often trifurcate tips of paraphyses and wavy to straight external hairs (e.g. Donadini 1987; Pérez-De-Gregorio et al. 2009; Domergue 2012; Boccardo et al. 2014; Carbone et al. 2014; Uzun \& Kaya 2018; Basso et al. 2019). It is a Mediterranean species typically growing on (or close to) roots of Erica arborea. It has been reported from France (Domergue 2012), Italy (Donadini 1987; Boccardo et al. 2014; Basso et al. 2019) including Sicily (Saitta 2020), Spain (Pérez-De-Gregorio et al. 2009; Rubio et al. 2013) including the Canary Islands (Ribes et al. 2015), and Turkey (Uzun \& Kaya 2018), and molecular data have been available only for the Spanish and Italian collections. In the present study we have added French, Greek and Portuguese collections as well as a topotype collection from Porquerolles Island (France).

Pseudoplectania tasmanica, described from Tasmania (Australia), shares most of the microscopical features with $P$. ericae, but has apothecia up to $3 \mathrm{~cm}$ in diameter. Beside larger and darker apothecia it differs from $P$. africana in straight external hairs and sometimes trifurcate paraphyses (Carbone et al. 2014).

Pseudoplectania affinis, described from New Zealand, can be distinguished mainly due to the straight external hairs in combination with a very diverticulated apex of the paraphyses and lack of large yellow crystals (Carbone et al. 2014).

Pseudoplectania melaena (in its wide sense including the American Peziza spongiosa Peck) can be easily distinguished due to much larger apothecia (up to $6 \mathrm{~cm}$ in diameter), usually longer stipe, larger ascospore sheath (judging freshly ejected ascospores), often hooked paraphyses, straight external hairs, absence of large yellow crystals and growth on mossy decayed Abies trunks (Van Vooren et al. 2013, Carbone et al. 2014).

Pseudoplectania nigrella differs in somewhat darker apothecia, larger ascospore sheath and absence of large yellow crystals. It is a common vernal species in the northern hemisphere inhabiting mossy soil and trunks of conifers, mainly Picea abies (Carbone \& Agnello 2012). As stressed by Carbone et al. (2014), P. nigrella most likely constitutes a complex of species, which are difficult to circumscribe at the current state of knowledge. At present we continue to follow Carbone et al. (2014) because a more detailed phylogenetic analysis conducted on this clade (data not shown here) seems to confirm the difficulty in separating the numerous lineages at species level.

Pseudoplectania lignicola differs from $P$. africana especially in its ascospores having a distinctly larger, centrally positioned sheath and by the absence of large 
yellow crystals. The species was reported from Slovakia and Czechia and distinguished from P. nigrella based on morphology and ecology. Our phylogenetic analysis included a collection of $P$. lignicola from the type locality in Slovakia and the paratype collection from Czechia, and confirmed the species belongs to the intricate nigrella-clade. Two collections (TUR 172564 from Finland and MCVE 27580 from Canada) previously sequenced and determined as $P$. nigrella (Carbone et al. 2014), fall into the lignicola-lineage as well. Re-examination of MCVE 27580 has shown that a few ascospores (the most immature) were surrounded by a centrally arranged globose membranous sheath, which is a characteristic feature of $P$. lignicola.

Pseudoplectania stygia, reviewed by Carbone (2013), clearly belongs to the $P$. nigrella clade, but recent material collected from the type locality is needed to clarify its concept also from a phylogenetic point of view.

Pseudoplectania episphagnum is a sister species of $P$. nigrella, with which it shares many microscopical features (e.g. the coiled external hairs). It can be distinguished from $P$. africana by its ecology (growth in bogs on Sphagnum spp.), size of apothecia usually smaller than $1 \mathrm{~cm}$, mostly bent paraphyses tips (Favre 1948; Kreisel 1962; Dennis 1969; Ulvinen 1976; Breitenbach \& Kränzlin 1981; Kristiansen 1990; Bauer 1999; Dissing \& Eckblad 2000; Spooner 2002; Carbone et al. 2014) and absence of large yellow crystals. In the tested specimens no or only very few hyaline crystals were found. In our study, LSU sequence of the isolectotype collection housed in the Conservatoire et Jardin botaniques de la Ville de Genève (G00566257; see Carbone \& Agnello 2015) was obtained, and an additional specimen from Spain was analysed. The isolectotype collection is identical in LSU with the collections from Spain and Finland.

Pseudoplectania sinica has recently been described from China (Zhang \& Zhang 2020) based on its asexual morph. Morphological comparison with $P$. africana is not possible, as the teleomorph of $P$. sinica is still unknown. Nevertheless, the genetic differences are distinct enough to be sure the species is not identical with $P$. africana.

Pseudoplectania carranzae is a species described from Costa Rica (Calonge \& Mata 2002), as Plectania carranzae. Beside the geographical disjunction it differs from $P$. africana in shorter asci $(170-200 \times 10-14 \mu \mathrm{m})$, ectal excipulum formed by a textura globulosa and curved paraphyses. Unfortunately, the loan of the holotype collection, housed in CR, for morphological and sequencing studies was not possible due to Costa Rican restrictions. Presence of crystals is not mentioned by the authors.

Pseudoplectania ryvardenii is so far known only from Venezuela, and it is distinguished from other Pseudoplectania species, including $P$. africana, mainly by its ornamented ascospores and the absence of the so-called hymenial hairs (Iturriaga et al. 2012). Unfortunately, due to Venezuelan restrictions, it has not been possible to obtain the holotype on loan for morphological and genetic studies (Neida Avendaño, curator of VEN, pers. comm.). The absence of hymenial hairs appears almost impossible to us, being a characteristic present in all the species of Pseudoplectania and Sarcosomataceae [apparently except Galiella amurensis (Lj.N.Vassiljeva) Raitv. (Popov \& Carbone 2021)]. Either way, the species as described in Iturriaga et al. (2012) seems to be distinct enough from our new species and therefore of low importance in this study.

\section{Conclusion}

Pseudoplectania africana is a new species described from South Africa, where it was collected on a decaying coniferous trunk. Among species of Pseudoplectania with available molecular data, $P$. ericae known from Europe and $P$. tasmanica from Tasmania are phylogenetically the closest. In contrast to other known Pseudoplectania species, these three species are characterised by presence of large yellow crystals in the tissues. Pseudoplectania africana represents the first published record of the genus from South Africa and probably also from the whole of African continent.

\section{Acknowledgements}

We are grateful to Carlo Agnello, Mijo Gomez, Viktorie Halasů, Viktor Kučera, Jean-Marc Moingeon, Enrique Rubio and Elsa Sousa for providing collections of Pseudoplectania, Vladimír Antonín (curator of BRNM), Miroslav Beran (curator of CB) and Tereza Tejklová (curator of HR) for loans of Pseudoplectania species, Philippe Clerc (curator of G) for the loan of Pseudoplectania episphagnum isolectotype, Riana Venter-Jacobs for information of the specimens of Pseudoplectania deposited in the PREM fungarium, Neida Avendaño (curator of VEN) for information on the holotype of Pseudoplectania ryvardenii, Edmund February for help with identification of the substrate of Pseudoplectania africana and Chris Yeates for the improvement of the English language. We also thank John C. Manning for financial support of the field work.

\section{Competing interests}

The authors declare that they have no financial or personal relationships that may have inappropriately influenced them in writing this article.

\section{Funding}

Michal Sochor was supported by grant No. RO0418 from Ministry of Agriculture, the Czech Republic, 
Zuzana Sochorová and Michaela Sedlářová by PrF2022-02 (IGA UP).

\section{Authors' contributions}

ZS performed the fieldwork, studied microscopical characters in the new species and crystals in most collections, wrote the article and took all of the photographs except those of nuclei, MC studied microscopical characters of the new species and wrote the first draft of manuscript, MSo performed phylogenetic analyses, MSe studied and documented nuclei in ascospores and AP studied crystals in five collections. All authors read and approved the final manuscript.

\section{References}

Barseghyan, G.S. \& Wasser, S.P., 2008, 'Species diversity of operculate discomycetes in Israel', Israel Journal of Plant Sciences 56(4), 341-348, https://doi.org/10.1560/ IJPS.56.4.341.

Basso, M.T., Cacialli, G., D'Ercole, A., 2019, 'Due ascomiceti interessanti dalla provincia di Pisa, Pseudoplectania ericae e Rutstroemia bolaris', Micologia Toscana 1, 37-57.

Bauer, G., 1999, 'Bavarian records of Pseudoplectania sphagnophila (Pers.: Fr.) Kreisel (Ascomycota, Sarcoscyphaceae)', Mycologia Bavarica 3, 44-49.

Boccardo, F., Carbone, M. \& Vizzini, A., 2014, 'Pseudoplectania ericae, una rara specie rinvenuta in Liguria (Italia)', Rivista Micologica Romana 92(2), 3-9.

Breitenbach, J. \& Kränzlin, F., 1981, Pilze der Schweiz. Vol. 1 (Ascomyceten). Mykologia, Luzern.

Calonge, F.D. \& Mata, M., 2002, 'Plectania carranzae sp. nov. (Ascomycotina) from Costa Rica', Mycotaxon 81, 237-241.

Carbone, M., 2013, 'A type study of Pseudoplectania stygia (Pezizales)', Ascomycete.org 5(1), 33-38, https://doi.org/ 10.25664/art-0078.

Carbone, M. \& Agnello, C., 2012, 'Studio e tipificazione di Pseudoplectania nigrella', Ascomycete.org 4(4), 79-93, https://doi.org/10.25664/art-0069.

Carbone, M. \& Agnello, C., 2015, 'Two typifications in Pseudoplectania (Ascomycota, Pezizales)', Ascomycete.org, 7 (2), 61-62, https://doi.org/10.25664/art-0129.

Carbone, M., Agnello, C. \& Alvarado, P., 2014, 'Phylogenetic and morphological studies in the genus Pseudoplectania (Ascomycota, Pezizales)', Ascomycete.org 6(1), 17-33, https://doi.org/10.25664/art-0095.

Deckerová, H. \& Šuhaj, J., 2014, 'Findings of the rare fungus Ebony Cup (Pseudoplectania nigrella) in Silesia and the northern Moravia', Acta Musei Beskidensis 6, 17-25.

Dennis, R.W.G., 1969, 'Two new British discomycetes with smooth spherical ascospores', Kew Bulletin 23(3), 479481, https://doi.org/10.2307/4117192.

Dissing, H. \& Eckblad, F.E., 2000, 'Key to the genus Pseudoplectania Fuckel'. In: Hansen L. \& Knudsen H. (eds.). Nordic Macromycetes. Vol. 1. Ascomycetes, Nordsvamp, Copenhagen.

Domergue, P., 2012, 'Une récolte de Pseudoplectania ericae Donadini', Bulletin semestriel de la Fédération des Associations Mycologiques Méditerranéennes 42, 21-28.

Donadini, J.-C., 1987, 'Étude des Sarcoscyphaceae ss. Le Gal (1). Sarcosomataceae et Sarcoscyphaceae ss. Korf. Le genre Pseudoplectania emend. nov. P. ericae sp.nov. (Pezizales)', Mycologia Helvetica 2(2), 217-246.
Doyle, J.J. \& Doyle, J.L., 1987, 'A rapid DNA isolation procedure for small quantities of fresh leaf tissue', Phytochemical Bulletin 19, 11-15.

Eckblad, F.-E., 1968, 'The genera of the operculate discomycetes. A re-evaluation of their taxonomy, phylogeny and nomenclature', Nytt Magasin for Botanikk 15(1-2), 1-191.

Favre, J., 1948, 'Les associations fongiques des hauts-marais jurassiens et de quelques régions voisines', Beiträge zur Kryptogamenflora der Schweiz 10(3), 1-228.

Gardes, M. \& Bruns, T.D., 1993, 'ITS primers with enhanced specificity for Basidiomycetes - application to the identification of mycorrhizae and rusts', Molecular Ecology 2(2), 113118, https://doi.org/10.1111/j.1365-294X.1993.tb00005.x.

Gates, G. \& Ratkowsky, D., 2016, A Field Guide to Tasmanian Fungi. 2nd edition. Tasmanian Field Naturalists Club.

Glejdura, S., Kučera, V., Lizoň, P. \& Kunca, V., 2015, 'Pseudoplectania lignicola sp. nov. described from central Europe', Mycotaxon 130(1), 1-10. https://doi.org/10.5248/130.1.

Henriot, A., Cheype, J.-L., 2020, Piximètre: La mesure de dimensions sur images. Version 5.10 R1540. http://ach.log. free.fr/Piximetre.

Iturriaga, T., Mardones, M. \& Urbina, H., 2012, 'A new species of Pseudoplectania (Sarcosomataceae, Pezizales) from Venezuela', Kurtziana 37(1), 73-78.

Kinge, T.R., Goldman, G., Jacobs, A., Ndiritu, G.G. \& Gryzenhout, M., 2020, 'A first checklist of macrofungi for South Africa', MyсоKeys 63, 1-48, https://doi.org/10.3897/mycokeys.63.36566.

Kreisel, H., 1962, 'Pilze der Moore und Ufer Norddeutschlands III. Pseudoplectania sphagnophila (Fr. pro var.) Kreisel nov. comb.', Westfalische Pilzbriefe 3(5), 74-77.

Kristiansen, R., 1990, 'Oransje greinbeger (Pithya vulgaris) og myrvårbeger (Pseudoplectania sphagnicola) i Østfold', Agarica 10-11 (19-20), 45-58.

Lanfear, R., Frandsen, P.B., Wright, A.M., Senfeld, T. \& Calcott, B., 2017, 'PartitionFinder 2: New methods for selecting partitioned models of evolution for molecular and morphological phylogenetic analyses', Molecular Biology and Evolution 34(3), 772-773, https://doi.org/10.1093/ molbev/msw260.

Le Gal, M., 1953, 'Les Discomycètes de Madagascar', Prodrome à une Flore mycologique de Madagascar 4, 1-465.

Lincoff, G.H., 1997, Field Guide to North American Mushrooms, National Audubon Society, Alfred A. Knopf, New York.

Medardi, G., 2006, Atlante fotografico degli Ascomiceti d'Italia, Associazione Micologica Bresadola. 
Otani, Y., 1973, 'On Pseudoplectania and Plectania collected in Japan', Reports of the Tottori Mycologicial Institute 10, 411-419.

Pant, D.C. \& Prasad, V., 2008, Indian Sarcoscyphaceous Fungi, Scientific Publishers (India).

Pérez-De-Gregorio, M.A., Carbó, J. \& Roqué, C., 2009, Algunos hongos interesantes de Girona, Fungi non Delineati 44: 1-100.

Popov, E. \& Carbone, M., 2021, 'Studies in Galiella (Ascomycota, Pezizales). V. Typification and study of Galiella amurensis', Ascomycete.org 13(3), 93-101. https://doi.org/10.25664/ art-0323.

Ribes, M.Á., Negrín, R., Quijada, L. \& Beltrán-Tejera, E., 2015, 'Contribución al conocimiento de la micobiota de las Islas Canarias (España) IV. Ascomycetes', Ascomycete. org 7(6), 375-393, https://doi.org/10.25664/art-0162.

Ronquist, F., Teslenko, M., van der Mark, P., Ayres, D.L., Darling, A., Höhna, S., Larget, B., Liu, L., Suchard, M.A. \& Huelsenbeck, J.P., 2012, 'MrBayes 3.2: Efficient bayesian phylogenetic inference and model choice across a large model space', Systematic Biology 61(3), 539-542, https:// doi.org/10.1093/sysbio/sys029.

Rubio, E., Gelpi, C., Suárez, J.A. \& Muñoz, J.M., 2013, 'Algunos Ascomicetes raros o interesantes recolectados en Extremadura', Boletín informativo de la Sociedad Micologica Extremena 13, 35-43.

Saitta, S., 2020, 'Prima segnalazione per la Sicilia di Pseudoplectania ericae e Donadinia lusitanica (Ascomycota, Pezizales)', Ascomycete.org 12(2), 47-56, https://doi.org/ 10.25664/art-0297.

Sandoval, P., 2012, 'Nuevos registros de Discomycetes (Pezizales) para la micobiota chilena', Gayana Botánica 69(2), 380-383.
Sanwal, B.D., 1953, 'Contributions towards our knowledge of the Indian Discomycetes. I. Some new records and new species of operculate Discomycetes', Sydowia 7(1-4), 191-199.

Seaver, F.J., 1913, 'The genus Pseudoplectania', Mycologia 5(6), 299-302, https://doi.org/10.2307/3753586.

Spooner, B., 2002, 'The larger Cup Fungi in Britain, part 4: Sarcoscyphaceae and Sarcosomataceae', Field Mycology 3(1), 9-14, https://doi.org/10.1016/S1468-1641(10)60122-3.

Ulvinen, T., 1976, Suursienopas, Suomen Sieniseura, Helsinki. Uzun, Y. \& Kaya, A., 2018, 'Plectania ericae, a new record for Turkey from Sarcosomataceae', Mantar Dergisi 9(2), 155-157, https://doi.org/10.30708/mantar.425533.

Van Vooren, N., Moyne, G., Carbone, M. \& Moingeon, J.-M., 2013, 'Pseudoplectania melaena (Pezizales): taxonomical and nomenclatural note', Ascomycete.org 5(1), 47-52, https://doi.org/10.25664/art-0080.

Van Wyk, B. \& van Wyk, P., 2013, Field guide to trees of Southern Africa, 2nd ed., Struik Nature.

Vilgalys, R. \& Hester, M., 1990, 'Rapid genetic identification and mapping of enzymatically amplified ribosomal DNA from several Cryptococcus species', Journal of Bacteriology 172(8), 4238-4246. https://doi.org/10.1128/ jb.172.8.4238-4246.1990.

White, T.J., Bruns, T., Lee, S. \& Taylor, J., 1990, 'Amplification and direct sequencing of fungal ribosomal RNA genes for phylogenetics', In: Innis, M.A., Gelfand, D.H., Sninsky, J.J. \& White, T.J. (eds), PCR protocols: A guide to methods and applications, New York, Academic Press, pp. 315-322, https://doi.org/10.1016/B978-0-12-372180-8.50042-1.

Zhang, Q. \& Zhang, J., 2020, 'A new species of the genus Pseudoplectania, P. sinica', Mycosystema 39(8), 14761486. https://doi.org/10.13346/j.mycosystema.200020. 


\section{Supplementary Material}

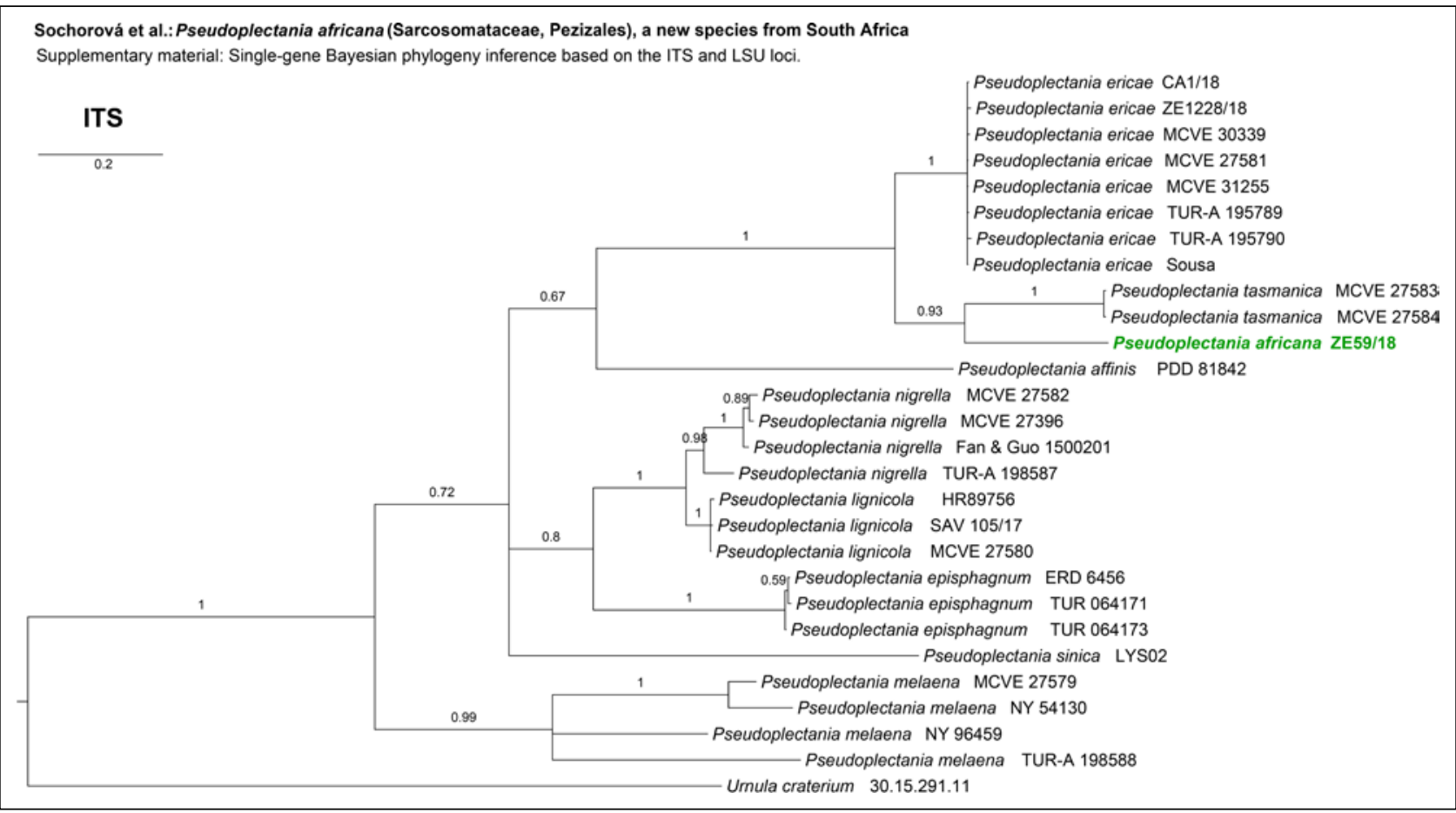

Supplementary Figure 1. Bayesian phylogeny inference based on ITS sequences. Bayesian posterior probabilities are shown above branches; Urnula craterium serves as an outgroup.

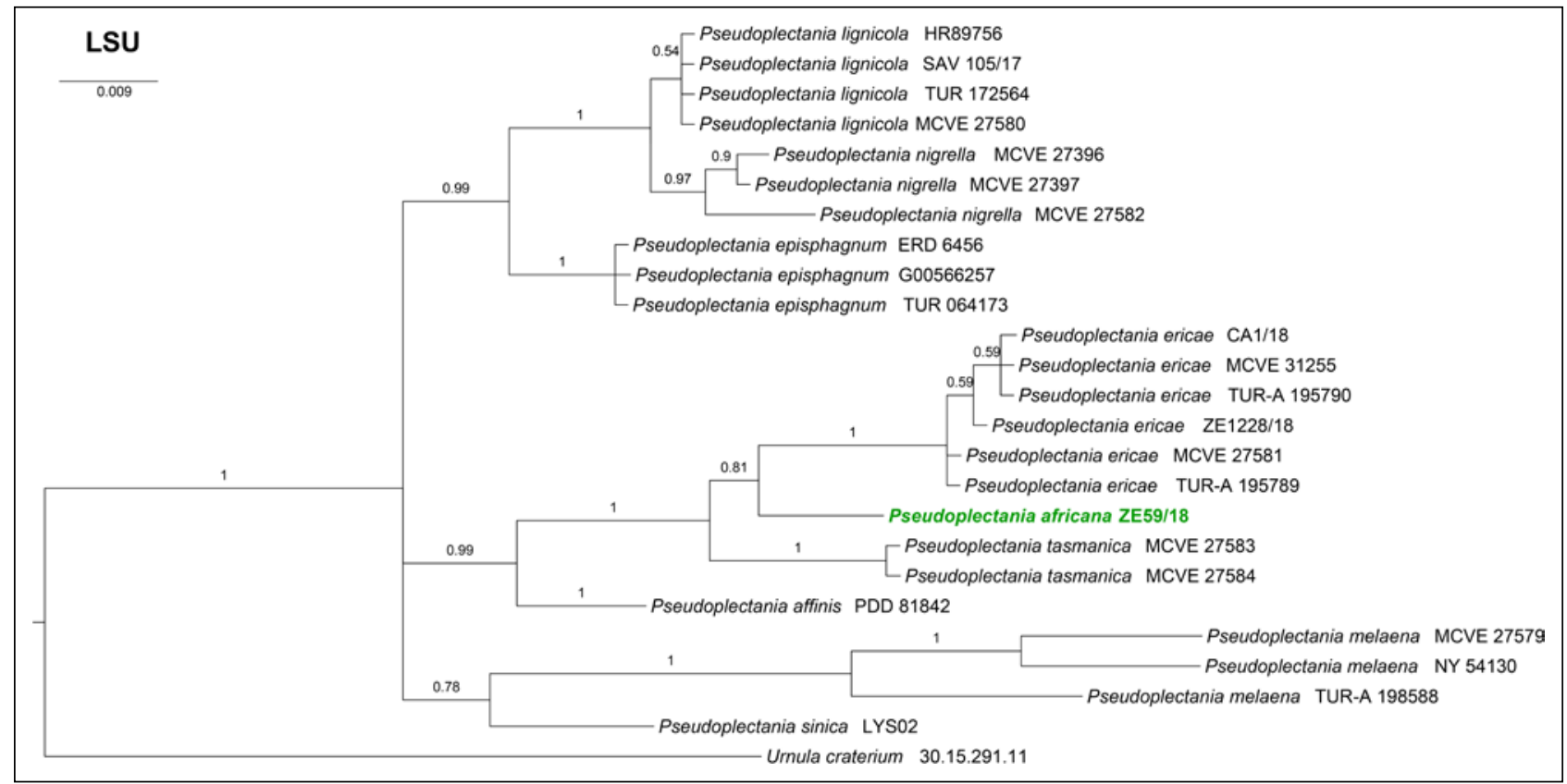

Supplementary Figure 2. Bayesian phylogeny inference based on LSU sequences. Bayesian posterior probabilities are shown above branches; Urnula craterium serves as an outgroup. 